ставкой в денежный поток с плавающей ставкой и сАелать выплаты по соответствующим траншам с плавающей ставкой. ОАним из таких инструментов являются процентные свопы, позволяющие участникам рынка обменивать платежи с плавающей ставкой на платежи с фиксированной ставкой, и наоборот. Несоответствие между обязательствами с плавающей ставкой по траншам и Аенежными потоками от активов, в которые инвестирует управцяющий, обосновывает целесообразность использования процентного свопа.
Таким образом, создание арбитражных CDO экономически выгодно только в том случае, если структура может обеспечить конкурентоспособную Аоходность по субординированному/миадшему траншу. При этом Аеятельность управляющего активами Аолжна быть сконцентрирована на систематическом контроле за выполнением обязательств и возмещении Аолгов. При этом эффективное управления портфе$\Lambda$ ем CDO существенно зависит от степени его Аиверсификации, что преАполагает вкмючение в портфель размичных типов обеспечения.

\title{
References:
}

1. Арбузов С. Г. Банківська енциклопедія./С. Г. Арбузов, Ю. В. Колобов, В. І. Міщенко, С. В. Науменкова. - К.: Центр наукових АосліАжень Національного банку України: Знання, 2011. - 504 с.

2. Котти С. Анализ ценных бумаг Грэма и АодАа./С. Коттл, Р. Мюррей, Ф. Блок; пер. с англ. - М.: ЗАО «Окимп-Бизнес», 2000. - 704 с.

3. Томсетт М.Биржевые секреты: опционы./М. Томсетт; пер. с англ. В. В. Найденова, А. В. Бушуева. - Смоменск: Русич, 2008. - 384 с.

4. Финансовые инструменты. /[под реА. Ф. Фабоцци; пер. с англ. Е. Востриковой, А. Ковалевского, М. Орлова]. - М.: Эксмо, 2010. - 864 с.

5. Хамл А. К. Опционы, фьючерсы и Аругие производные финансовые инструменты./А. К. Хамл. - М.: ИзАатемьский Аом «Вимьямс», 2008. - 1044 с.

6. Fabozzi F. Finance: capital markets, financial management and investment management./F. Fabozzi, P. Peterson Drake. - Hoboken, New Jersey: John Wiley \& Sons, 2009. - 812 p.

7. Fabozzi F. Interest Rate and Credit Risk./F. Fabozzi, S. Mann, M. Choudhry. - Hoboken, New Jersey: John Wiley \& Sons, 2003. - 533 p.

8. Graham B. Security Analysis: Principles and Technique./B. Graham, D. Dodd. - N. Y.: McGraw-Hill, 2009. - 766 p.

Tsintsadze Asie Enverovna,

Full Prof., at the Faculty of Economics and Business, Administartion of Batumi Shota Rustaveli State University

E-mail:asinsaze@rambler.ru

Meloyan-Phutkaradze Lilit Zohrakovna, Assistant Prof., at the Faculty of Economics and Business

E-mail: lilmeloyan@yahoo.com

\section{Pension system perfection problems in Georgia}

Abstract: Despite of the fact, that Georgia is developing its market economy with a normal growing rate, it has never had such pension system that could give enough pensions to pensioners for stable life conditions. The work is focused on Georgian cumulative pension schemes. We review what problems and shortcomings are in Georgian private pension schemes, than we try to distinguish and pick up main points.

Keywords: Social Security, Social Insurance, Pension System, Private Pension.

\section{Introduction}

The social security system consists of the following mechanisms: social assistance, social insurance, social security. It's obvious that influence object for each mechanism is human being, who becomes disabled due to different reasons: disability, illness, old age and the circumstances related to child delivery and care.

Each beneficiary at first glance is the subject of care of State Social Policy, but if we take into account the fact that the existence of the state is related to the use of income 
received from each citizen in his/her period of capacity for work in order to perform its goals and objectives. It is easy to understand that the state pension is affected by the following factors: the level of economic development, the average salary, pension fund provision, the aging index, employment, tax legislation. Citizen who in his/her period of capacity for working was marked by a high level of life, forcing him/her to continue to live in the minimum wage in accordance with the retirement age. Such an approach, in our opinion puts a person's psychological and moral damage shot. This in turn reduces the risk of concealment of income growth and employment incentives. In Countries of developed economy there is almost no relevance to the subsistence minimum pension.

\section{Experience of Foreign Countries}

In most cases to minimum standards relevant pension is added labor retirement pension and according to private pension schemes accumulated financial resources and as a result can be achieved $20-70 \%$ salary with pension replacement ratio. For example, $20 \%$ of the average wages in the UK - is the state pension, and labor pension is at the expense of contributions of about $20 \%$. In France $50 \%$ of average wage, in Sweden $70 \%$ [1].

In majority of countries (USA, Norway, Ecuador, Japan, and Great Britain) the pension system is two or threelevel system, resulting in high levels of financial support for the old age is reached. It should be noted that those countries are involved in the formation of the pension fund and pension contributions for all employees on the basis of the principle of solidarity by previous generations of funding. Such an approach is known as "fair system".

\section{State Pension Mechanism in Georgia}

In our opinion, the minimum wage equal pension goes beyond the framework of the pension system and looks like social security mechanism. As you can see Social Security system cannot be the way, the recipients who receive it may deem themselves as worthy citizen. In Georgia the average salary is 773.1 GEL [10], $20 \%$ of which is 155 GEL, It is actually in compliance with developed countries I level pension system state retirement pension system replacement coefficient, as for II level of the pension system, labor pension is as follows: Georgian Government Resolution No. 181 of August 29, - according to the work experience determines approved state pension supplements. According to the aforementioned resolution of September 1, 2007, the old age person in case of work experience, by submitting work experience document to receive additive as follows [7]:

a) For the pensioners with the total work experience up to 5 years -2 GEL; b) For the pensioners with the total work experience from 5 to 15 years - 4 GEL;

c) For the pensioners with the total work experience from 5 to 25 years - 7 GEL;

d) For the pensioners with the total work experience 25 years and more - 10 GEL.

The above information is based on the unfair principles as the difference between the additives is beyond any criticism.

Multilevel pension system allows citizens by saving their income in old age ensure high pension. Key element is the pension fund, and in its formation takes part the government, and employer and employee by determining mathematically calculated retirement allowance, as for private pension schemes, in the former Soviet Union countries it turned into financial pyramid and lost the trust of the population. There is no perfect pension system, that's why all countries according to above factors has established the own model of the pension system, which cannot be effective if it will be copied by other countries. Analysis of the factors influencing the pension system in Georgia gave the following picture: according to GDP per capita between 180 countries Georgia ranked $112^{\text {th }}$, the average annual income of GEL 6000, the employment level output $85.4 \%$, among them the self-employed $-61 \%$. The developed Western countries (Germany, France, Italy) $16-20 \%$ of the total population of pensioners. In Georgia, this ratio is $15 \%$. According to these data as if should be provided happy old age, but the number of employed citizens (1712.1 thousand) and the number of retirees (686700) compared we see that for 1 employee comes 2.5 retired. It is hard to imagine, since the income tax of employee is a major source for pension provision. The pension system, which is based on income tax receipts, stimulates not savings but corruption and shadow economy as a part of income tax, because regardless the amount of the deposit the result is the same after retirement age [10].

\section{Private Pension Schemes in Georgia}

Twenty years independence period of Georgia is created with the hard history of pension system. In Georgia today actively operates "Aldagi BCI" pension scheme. "Aldagi $\mathrm{BCI}$ " pension fund preserves its leading position in pension scheme market of Georgia. It is the largest pension fund in Georgia, jointly managed by "Abby Asset Management" and JSC "Aldagi BCI". According to The National Bank of Georgia results of the fourth quarter of 2012, the fund remains the undisputed leader on the pension market of Georgia. According to the publication, "Aldagi BCI" pension scheme market share is 79.0\% [8]. 
According to the latest data, regarding "Aldagi BCI pension fund - in 2013, we have further indicators:

- Aldagi BCI assets cumulative income increased for $494 \%$, from 1.5 Million GEL up to 9,0 million GEL;

- Aldagi BCI Market Share increased from $23 \%$ up to $74 \%$;

- Aldagi BCI Pension Fund participants number increased from 5,000 up to 7,000 (Table 1).

The second pension scheme, that operates in difficult conditions is GPI holding pension scheme. GPI Holding was established in 2001 as the first private pension fund in Georgia. Company's 13 years in this system indicates its stability and rich experience, and that makes it as one of the leading pension scheme [9].

In case of joining GPI Holding private pension scheme:
- You will have your own pension account, where accumulation is made in the currency upon your choice GEL or USD;

- The minimum contribution is $10 \mathrm{GEL}$, deposits shall be made for any time periods: monthly, quarterly, annually, etc.;

- Your pension fund is constantly working and interest is accrued annually, even after retirement (!);

- For retirement age, you will have your pension saving, which will give you possibility to independent and financially secure old age.

The funds deposited by the client will be located in the investment portfolio, the payoff is not known in advance and it can be higher than bank interest rates.

Below is proposed over the past five years data about, what percentage imposed GPI Holding to client's annual savings (Table 2).

Table 1. - During 2012 the information regarding activities carried out by founders of the pension schemes (GEL) (source: Insurance Monitoring Office of Georgia)

\begin{tabular}{|c|c|c|c|c|c|c|}
\hline Organization name & 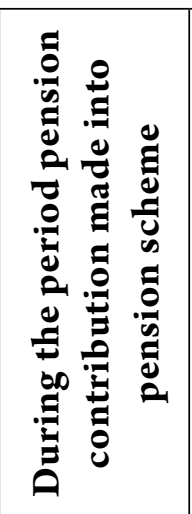 & 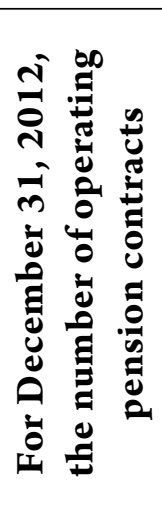 & 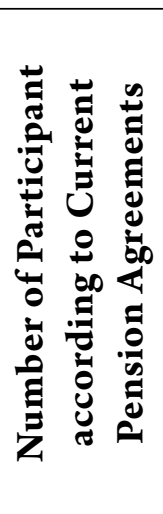 & 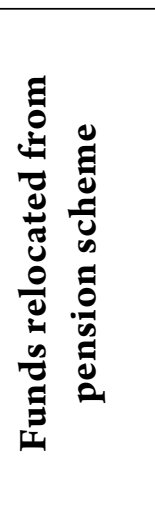 & 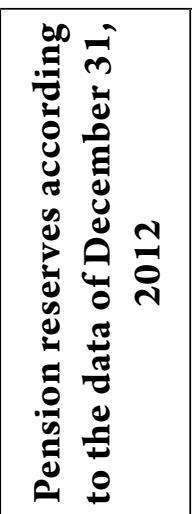 & 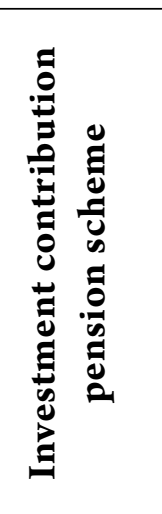 \\
\hline $\begin{array}{l}\text { JSC “Insurance Company Aldagi } \\
\text { BCI” }\end{array}$ & 1910331 & 339 & 6906 & 655878 & 8100450 & 773331 \\
\hline $\begin{array}{l}\text { JSC “Insurance Company GPI } \\
\text { Holding” }\end{array}$ & 496925 & 11463 & 11491 & 334590 & 3189244 & 232846 \\
\hline $\begin{array}{l}\text { JSC International Insurance Com- } \\
\text { pany “Imedi L International” }\end{array}$ & 7900 & 3 & 27 & 232667 & 48163 & 10498 \\
\hline Insurance Company “TAO” Ltd. & 0 & 0 & 0 & 0 & 0 & 0 \\
\hline $\begin{array}{l}\text { International Insurance Company } \\
\text { “IRAO” Ltd. }\end{array}$ & 0 & 0 & 0 & 0 & 0 & 0 \\
\hline “Insurance Company ALFA" Ltd. & 0 & 0 & 0 & 0 & 0 & 0 \\
\hline Total & 2415156 & 11805 & 18424 & 122535 & 11337857 & 1016675 \\
\hline
\end{tabular}

Table 2. - (source: [9])

\begin{tabular}{|l|c|c|c|c|c|c|c|}
\hline & $\mathbf{2 0 0 6}$ & $\mathbf{2 0 0 7}$ & $\mathbf{2 0 0 8}$ & $\mathbf{2 0 0 9}$ & $\mathbf{2 0 1 0}$ & $\mathbf{2 0 1 1}$ & $\mathbf{2 0 1 2}$ \\
\hline Profitability of Pension Fund & $10 \%$ & $11 \%$ & $11 \%$ & $10 \%$ & $10 \%$ & $9,3 \%$ & $8 \%$ \\
\hline
\end{tabular}

As we can see from the table GPI Holding offered its clients average $9.9 \%$ profitability in recent years.

Despite the fact that today Georgia has two-column pension system, still it doesn't give desired result to the population. The first component is the state pension, and the second component — work and merit-based pension supplement and the third voluntary pension savings system, which is virtually developed in negligible pace.

In a situation when the state pension system becomes deficient, old age makes it difficult to maintain decent living conditions. For private pension system establishment 
the government should start a private saving pension scheme promotion and popularization.

Nowadays attempts to modify the current model cannot meet the challenges, which are apparent and increasingly inadequate to the realities of life existing retirement system.

\section{Recommendations for the Creation of a} Perfect Pension System

The current pension system is inherently instrument of social assistance, which only mitigates the condition to vulnerable pensioners, but can not guarantee the basic living needs.

Therefore, a number of steps necessary to ensure that the pension system is an effective mechanism, to involve private initiative and not remain subject of responsibility for inflexible state mechanism.

In order to provide these changes it is necessary to consider and implement the following recommendations:

- Political and legislative decisions regarding putting into force pension system second column;

- Create transparent and clear rules of the game in the country's pension funds, asset management companies establishment and activities, in order to minimize the risks and strict supervision;

- Identifying problems of the transitional period and take the appropriate measures for minimizing risks;

- Identifying sources of financing the cost during the transitional period;

- Retirement, using savings and their own individual accounts management and clearly determining possibilities of flow;

- Minimal state pension and its usage guarantees determination and legalization;

- Revision of minimal pension age regarding possible increase and equalization;

- The possibility of early retirement after a strict and substantiated regulate;

- The formation of a complex pension system for citizens with various income;

- Directions for investing pension assets, given that the stock market is still in the embryonic stages in Georgia;

- Enacting the practice of pension contributions.

The savings system allows a more easy solving regarding the number of the working population which is related to the problem of distribution system: Together with aging of the population, decreasing the number of employees who have to provide one retired. In the conditions of the savings system, the employed population doesn't have to keep pensioners. On the contrary, unlike the distribution system, intergenerational conflict disappears without any basis and the possibility of bankruptcy of the entire system. In new system we will not have unfulfilled pension obligation by government, still many countries face this problem.

Transition to a new system will not be an easy process. In transitional stage we can use three rules:

- The government should give assurances to those who already receive a pension, that the pension reform will not concern them;

- Each employee which has already made contributions to the old age distribution system, will receive the right of the choice whether stay or move to a new savings system;

- For every person, who will join employees in the current period, it will be required to get engaged in any of them - the old or the new system, the state distribution system.

The financial reports of pension schemes shall be reviewed at least twice a year, which will enable the population feel confident that they will have stable living conditions at their old age.

Those workers who had already paid their contributions to the distributive pension system, were allowed to make the choice between the two models.

Who will remain in the distribution scheme will receive the basic state pension. Anyone who decides to move into savings scheme, they will receive government bonds, that will be used to compensate the earlier contributions. The bonds will be redeemed by the government at the moment of retirement. This will allow the person who has made income contributions to the budget; shift the amount into retirement savings scheme.

The current tax system, in particular the declaration issued by the employers' organizations on the payroll of salaries, which is monthly sent to Revenue Service allows decoding who, when and what amount paid into the budget, in terms of income tax.

\section{Conclusion}

Obviously at the initial stage at the pension security sphere establishment of mechanisms facilitating private schemes will partially decrease those revenues that are gathered in tax regime. However, in the long term it will encourage pension schemes setting into motion and will promote a new type of institutional investors - establishment of private pension funds, whose work also provides additional economic activity and, therefore, payment of the taxes. 


\section{References:}

1. Якобсон А.И., Полищук $\Lambda$.И., Беневоленский В.Б. Пенсионная система: модель Аля россии и зарубежный опыт. - М.: РеАакционная коммегия серии «Независимый экономический анализ», 2003.

2. Pension reform 2013. Annual Report. - Global and Georgian Perspective EPRC.

3. Georgian Law Regarding Non-state Pension Insurance and Activities.

4. Geletashvili Nino. Chilean Pension Reform: Its Essence and Meaning for Georgia. - 2013.

5. Annual Report of National Bank of Georgia. - 2013.

6. Law of Georgia Regarding State Pension.

7. Resolution No. 181, 2007, 29 August of the Government of Georgia: "Defining appendage to the state pension according to the length of service considering pension age".

8. Insurance Company ALDAGIBCI.// [Electronic resource]. - Available from: http://www.aldagibci.ge/pensionfund/

9. Insurance Company GPI HOLDING.// [Electronic resource]. - Available from: https://www.gpih.ge/gpih/pensionfund/

10. National Statistics Office of Georgia.// [Electronic resource]. - Available from: http://geostat.ge/

Yadgarova Malika Lutpillaevna, Tashkent Financial Institute, Senior teacher, Department of "Banking"

Hudoyarova Hurshida Abdinazarovna, Senior teacher, Department of "Banking"

E-mail:nasibaturgunowna@mail.ru

\section{The role of monetary policy in macroeconomic regulation Uzbekistan}

Abstract: Minimum (mandatory) reserves - is the most liquid assets, which are required to have all credit institutions, as a rule, either in the form of cash on hand or in the form of deposits with the Central Bank or other forms of highly determined by the Central Bank Uzbekistan.

In Uzbekistan, the impact of this policy in the money supply is used as the main tool.

Keywords: monetary sphere, bank deposit, inflation, liquidity.

Ядгарова Малика Аутпилмаевна, Ташкентский Финансовый институт, стариий преподаватель, кафедра "Банковское дело"

Худалрова Хуршида Абдиназаровна, стариий преподаватель, кафедра "Банковское дено"

E-mail:nasibaturgunowna@mail.ru

\section{Роль денежно-кредитной политики в макроэкономическом регулировании Узбекистана}

Аннотация: Минимальные (обязательные) резервы - это наиболее киквидные активы, которые обязаны иметь все кредитные учреждения, как правило, либо в форме наличных денег в кассе банков, мибо в виде Аепозитов в Центральном банке или в иных высоколиквидных формах, определяемых Центральным банком. Узбекистана. В Узбекистане влияние этой политики в структуре Аенежной массы используется в качестве основного инструмента.

Ключевые смова: денежно-кредитная сфера, банковский депозит, инфмяция, ликвидность. 